\title{
Formulation Factors of Pyrethroid Microcapsules Affecting Rainfastness, Phytotoxicity and Mammalian Toxicity
}

\author{
Toshiro Ohtsubo, Hisami Takeda, Shigenori Tsuda \\ and Kozo Tsuji \\ Agricultural Science Research Laboratory, Takarazuka Research Center, \\ Sumitomo Chemical Co., Ltd., Takatsukasa, Takarazuka 665, Japan
}

(Received November 16, 1990)

\begin{abstract}
Effects of formulation factors such as mass median diameter $(D)$ and wall thickness $(T)$ on the rainfastness, phytotoxicity and acute mammalian toxicity of fenvalerate and fenpropathrin microcapsules were investigated. The rainfastness of fenvalerate microcapsules to cabbage was mainly regulated by $T$, increasing with a decrease in $T$. The microcapsules with $T$ of less than $c a .0 .05 \mu \mathrm{m}$ was superior to a fenvarelate emulsifiable concentrate in rainfastness. $D$ was not a dominant factor, although the effect was not negligible. The phytotoxicity of fenvalerate microcapsules to cabbage, Chinese cabbage and cucumbers decreased with an increase in $T$. $D$ was not a dominant factor, although the effect was not clear. The acute oral toxicity of fenpropathrin microcapsules in rats decreased with an increase in $D \cdot T$. It seemed to be regulated by the release rate of the active ingredient from the microcapsules.
\end{abstract}

\section{INTRODUCTION}

New types of pesticides formulations with new useful functions, e.g., concentrated emulsions, suspension concentrates, dry flowables and microcapsules, have been developed in the agricultural field. ${ }^{1-5)}$ At the same time, many studies have been done on microencapsulated pesticides in order to improve residual efficacy, mammalian toxicity, fish toxicity, phytotoxicity, etc. ${ }^{6-8)}$ Advantages of microencapsulation may be related to formulation factors such as wall material, particle size and wall thickness that regulate physicochemical and physical properties of microcapsules. ${ }^{9)}$

In the previous study, ${ }^{10)}$ we investigated the efficacy of fenvalerate microcapsules against caterpillar insects and their fish toxicity. The efficacy was regulated by the parameter $D / T$, the ratio of mass median diameter $(D)$ to wall thickness $(T)$, and the fish toxicity was regulated by $D \cdot T$, which was the product of $D$ and $T$.

In the present study, we examined the effects of formulation factors $(D$ and $T)$ on rainfastness, phytotoxicity and acute mammalian toxicity using fenvalerate and fenpropathrin microcapsules.

\section{MATERIALS AND METHODS}

\section{Microencapsulation Procedure}

Fenpropathrin microcapsules were prepared by interfacial polymerization of polyisocyanate and $\mathrm{H}_{2} \mathrm{O}$. The wall material was polyurea. ${ }^{11)}$ The content of fenpropathrin was $10 \mathrm{wt} \%$ in the final slurry. The mass median diameter $(D)$ was controlled by changing mixing conditions when a mixture of fenpropathrin and polyisocyanate was dispersed in water containing gum arabic. Actual $D$ was measured after preparation with a Coulter Counter 
Table 1 Fenvalerate 10 wt $\%$ microcapsules. ${ }^{10}$ )

\begin{tabular}{cccr}
\hline $\begin{array}{c}\text { Sample } \\
\text { No. }\end{array}$ & $\begin{array}{c}\text { Wall } \\
\text { thickness } \\
T(\mu \mathrm{m})\end{array}$ & $\begin{array}{c}\text { Mass median } \\
\text { diameter } \\
D(\mu \mathrm{m})\end{array}$ & $D / T$ \\
\hline 1 & 0.002 & 4.8 & 2400 \\
2 & 0.002 & 31.0 & 15,500 \\
3 & 0.005 & 2.0 & 400 \\
4 & 0.011 & 4.8 & 436 \\
5 & 0.011 & 52.0 & 4727 \\
6 & 0.038 & 4.3 & 113 \\
7 & 0.051 & 22.5 & 441 \\
8 & 0.113 & 50.0 & 442 \\
\hline
\end{tabular}

Table 2 Fenpropathrin $10 \mathrm{wt} \%$ microcapsules.

\begin{tabular}{cccc}
\hline $\begin{array}{c}\text { Sample } \\
\text { No. }\end{array}$ & $\begin{array}{c}\text { Wall } \\
\text { thickness } \\
T(\mu \mathrm{m})\end{array}$ & $\begin{array}{c}\text { Mass median } \\
\text { diameter } \\
D(\mu \mathrm{m})\end{array}$ & $D \cdot T\left(\mu \mathrm{m}^{2}\right)$ \\
\hline 1 & 0.002 & 4.5 & 0.009 \\
2 & 0.004 & 8.8 & 0.035 \\
3 & 0.009 & 8.6 & 0.077 \\
4 & 0.010 & 4.9 & 0.049 \\
5 & 0.010 & 19.3 & 0.193 \\
6 & 0.020 & 19.8 & 0.396 \\
7 & 0.022 & 10.9 & 0.240 \\
8 & 0.041 & 20.3 & 0.832 \\
\hline
\end{tabular}

Model TA-II (Coulter Electronics Inc.). The wall thickness $(T)$ was controlled by changing the ratio of polyisocyanate to fenpropathrin and $D$. Actual $T$ was calculated by using Eq. $(1) \cdot{ }^{12)}$

$$
T=\left(W_{\mathrm{w}} / W_{\mathrm{c}}\right)\left(\rho_{\mathrm{c}} / \rho_{\mathrm{w}}\right)(D / 6)
$$

where $W_{\mathrm{w}}$, weight of wall material; $W_{\mathrm{c}}$, weight of core material; $\rho_{\mathrm{w}}$, density of wall material; $\rho_{\mathrm{c}}$, density of core material and $D$, mass median diameter.

The microencapsulation procedure of fenvalerate $10 \mathrm{wt} \%$ microcapsules was the same as described in our previous paper. ${ }^{10)}$

The microcapsules used in this study are summarized in Tables 1 and 2.

\section{Rainfastness Test of Fenvalerate $10 w t \%$ Microcapsules on Cabbage}

The fenvalerate microcapsules shown in Table 1 and a fenvalerate $20 \mathrm{wt} \%$ emulsifiable concentrate were diluted to $100 \mathrm{ppm}$ fenvalerate with water and sprayed on potted cabbage (Shikidori). In the case of the
Table 3 Criterion for observing phytotoxicity.

\begin{tabular}{cc}
\hline Index & Damaged area on a leaf \\
\hline 0 & 0 \\
1 & less than $5 \%$ \\
2 & $5 \%-30 \%$ \\
3 & $30 \%-60 \%$ \\
4 & $60 \%-80 \%$ \\
5 & more than $80 \%$ \\
\hline
\end{tabular}

fenvalerate microcapsules, $200 \mathrm{ppm}$ Tokusei Rino (Nihon Nohyaku Co., Ltd.) was added into the dilution as a wetting agent. Artificial rainwashing $(40 \mathrm{~mm}$ of rain per hour) was conducted immediately after spraying and at 90 min after drying with artificial rainwashing equipment DIK-6000 (Daikirikakogyo Ltd.). After air drying, a treated leaf was cut off and ten 3rd-instar larvae of tobacco cutworm, Spodoptera litura, were confined to contact with the leaf in a plastic cup (12 cm i.d.). The mortality was determined after $48 \mathrm{hr}$.

\section{Phytotoxicity Test of Fenvalerate $10 w t \%$ Microcapsules}

The fenvalerate microcapsules were diluted to $400 \mathrm{ppm}$ fenvalerate with water containing 200 ppm Tokusei Rino as a wetting agent and sprayed on potted cabbage (Shikidori), Chinese cabbage (Muso) and cucumbers (Hokushin). Phytotoxicity was observed after 1 week using the criterion shown in Table 3 , and the degree of phytotoxicity was calculated by using Eq. (2).

Index of the degree of phytotoxicity

$$
=\frac{\sum\left(\begin{array}{l}
\text { index of damaged area } \\
\times \text { number of classified leaves }) \times 100
\end{array}\right.}{(\text { total number of leaves observed }) \times 5}
$$

where index of damaged area $=$ index in Table 3 and number of classified leaves $=$ number of leaves classified into the corresponding index in Table 3.

4. Determination of Mammalian Toxicity of Fenpropathrin $10 w t \%$ Microcapsules in Rats

The fenpropathrin microcapsules were orally administrated to 7 week old SD rats (Crs$\mathrm{CD})$. The acute oral $\mathrm{LD}_{50}(\mathrm{mg} / \mathrm{kg})$ of each 
microcapsule was evaluated and compared with that of the fenpropathrin $10 \mathrm{wt} \%$ emulsifiable concentrate. The relative toxicity was calculated by using Eq. (3).

$$
\begin{aligned}
& \text { Relative toxicity }(\%) \\
& =\frac{\left(\text { acute oral } \mathrm{LD}_{50} \text { of } \mathrm{EC}\right) \times 100}{\left(\text { acute oral } \mathrm{LD}_{50} \text { of } \mathrm{MC}\right)}
\end{aligned}
$$

where EC, fenpropathrin $10 \mathrm{wt} \%$ emulsifiable concentrate and $\mathrm{MC}$, fenpropathrin $10 \mathrm{wt} \%$ microcapsule.

\section{RESULTS AND DISCUSSION}

\section{Rainfastness of Fenvalerate Microcapsules on Cabbage}

Figure 1 shows the relationship between $D / T$, the ratio of mass median diameter to wall thickness, and the mortality of S. litura with fenvalerate microcapsules without rainwashing. The mortality with sample No. 6 with low $D / T$ was low, whereas the mortality with samples with $D / T$ of more than 400 was almost $100 \%$. Our previous paper ${ }^{10)}$ reported that the $D / T$ of fenvalerate microcapsules affected the efficacy against $S$. litura and that the $\mathrm{LC}_{50}$ value decreased with increasing in $D / T$. In the present study, we reconfirmed that the efficacy of the microcapsules increased with increasing in $D / T$.

As shown in Table 4, the mortality was lower after rainwashing than without rain-

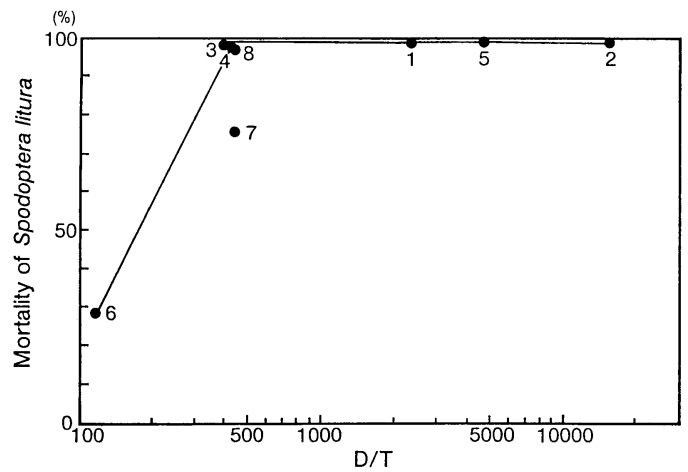

Fig. 1 Relationship between $D / T$ and the mortality of Spodoptera litura with fenvalerate 10 wt $\%$ microcapsule without rainwashing.

No. in the figure, sample No. of fenvalerate 10 wt $\%$ microcapsule; $D / T$, the ratio of mass median diameter to wall thickness.
Table 4 Rainfastness of fenvalerate $10 \mathrm{wt} \%$ microcapsules.

\begin{tabular}{cccc}
\hline & \multicolumn{3}{c}{ Mortality of Spodopteva litura (\%) } \\
\cline { 2 - 4 } $\begin{array}{c}\text { Sample } \\
\text { No. }\end{array}$ & $\begin{array}{c}\text { No } \\
\text { rainwashing }\end{array}$ & $\begin{array}{c}\text { Rainwashing } \\
\text { immediately } \\
\text { after } \\
\text { spraying }\end{array}$ & $\begin{array}{c}\text { Rainwashing } \\
\text { after } \\
\text { drying }\end{array}$ \\
\hline 1 & 98 & 91 & 94 \\
2 & 98 & 99 & 96 \\
3 & 98 & 96 & 86 \\
4 & 98 & 63 & 95 \\
5 & 99 & 93 & 91 \\
6 & 29 & 15 & - \\
7 & 74 & 0 & 14 \\
8 & 99 & 3 & 6 \\
\hline EC $^{\text {a }}$ & 95 & 52 & 88 \\
\hline
\end{tabular}

a) Fenvalerate $20 \mathrm{wt} \%$ emulsifiable concentrate.

washing, especially with samples No. 7 and 8 . The mortality did not differ much whether rainwashing was done immediately after spraying or after drying.

To clarify the relationship between formulation factors such as $D$ and $T$, and rainfastness, we introduced the rainfastness factor (RF) calculated by using Eq. (4) as a parameter of rainfastness.

$$
R F(\%)=\left(M_{\mathrm{rs}}\right) /\left(M_{\mathrm{nr}}\right) \times 100
$$

where $M_{\mathrm{rs}}$, mortality of $S$. litura rainwashed immediately after spraying and $M_{\mathrm{nr}}$, mortality of S. litura not rainwashed.

Figure 2 shows the relationship between $D / T$ and $R F$. In the samples with $D / T$ of around $400, R F$ varied in the range of 0 to $100 \%$, which means $D / T$ that regulated the mortality without rainwashing was not the parameter that controlled the mortality after rainwashing.

Figure 3 shows the effect of $D$ on $R F$ when $T$ was constant. When $T$ was $c a .0 .01 \mu \mathrm{m}$, $R F$ increased with increasing in $D$. When $T$ was $0.002 \mu \mathrm{m}$, however, $R F$ did not increase so remarkably. Figure 4 shows the effect of $T$ on $R F$. The lower the $T$, the higher the $R F$, and the effect of $D$ was not so significant. The $R F$ of the microcapsule with $T$ of more than $0.05 \mu \mathrm{m}$ was almost zero. On the other hand, the microcapsule with $T$ of less than $c a$. $0.02 \mu \mathrm{m}$ had a higher $R F$ than the fenvalerate 


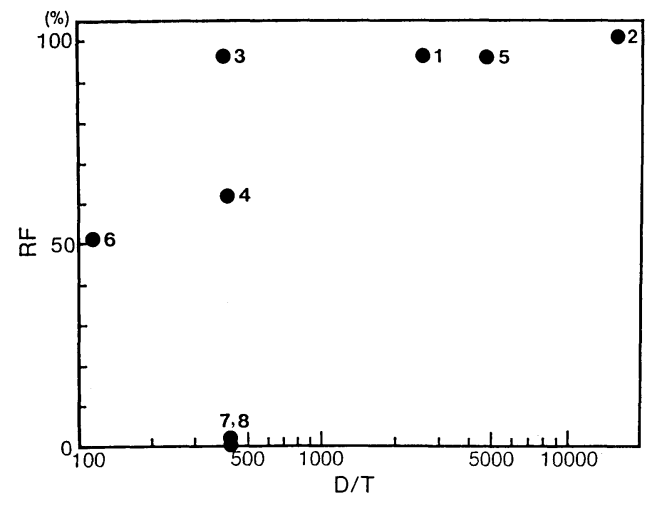

Fig. 2 Relationship between rainfastness factor $(R F)$ and $D / T$ of fenvalerate $10 \mathrm{wt} \%$ microcapsule.

No. in the figure, sample No. of fenvalerate 10 wt $\%$ microcapsule; $D / T$, the ratio of mass median diameter to wall thickness; $R F,\left(M_{\mathrm{rs}}\right) /$ $\left(M_{\mathrm{nr}}\right) \times 100$, where $M_{\mathrm{rs}}=$ mortality of Spodoptera litura with rainwashing immediately after spraying and $M_{\mathrm{nr}}=$ mortality of Spodoptera litura without rainwashing.

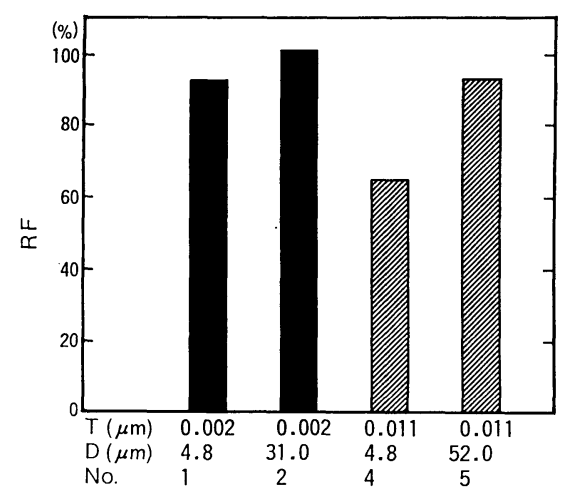

Fig. 3 Relationship between rainfastness factor $(R F)$ and $D$ of fenvalerate $10 \mathrm{wt} \%$ microcapsule.

No. in the figure, sample No. of fenvalerate 10 wt $\%$ microcapsule; $D$, mass median diameter; $T$, wall thickness; $R F,\left(M_{\mathrm{rs}}\right) /\left(M_{\mathrm{nr}}\right) \times 100$, where $M_{\mathrm{rs}}=$ mortality of Spodopteva litura with rainwashing immediately after spraying and $M_{\mathrm{nr}}=$ mortality of Spodoptera litura without rainwashing.

emulsifiable concentrate (55\%).

From the above discussion, it was concluded that $T$ mainly affected the rainfastness of the microcapsule and that $D$ was not a dominant

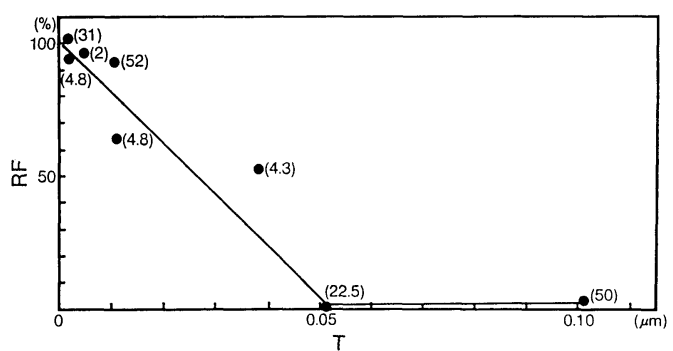

Fig. 4 Relationship between rainfastness factor $(R F)$ and $T$ of fenvalerate $10 \mathrm{wt} \%$ microcapsule.

$T$, wall thickness; $R F,\left(M_{\mathrm{rs}}\right) /\left(M_{\mathrm{nr}}\right) \times 100$, where $M_{\mathrm{rs}}=$ mortality of Spodoptera litura with rainwashing immediately after spray and $M_{\mathrm{nr}}=$ mortality of Spodoptera litura without rainwashing; figures in ( ), mass median diameter.

factor although the effect of $D$ was not negligible. It is not clear at this stage why $T$ mainly affects $R F$. Since the degree of rainfastness is supposed to be affected by the binding strength between plant surface and microcapsule after spraying, research on binding strength may be required to make clear the mechanism of rainfastness of microcapsules.

\section{Phytotoxicity of Fenvalerate 10 w $\%$ Micro- capsules}

Figure 5 shows the degree of phytotoxicity of the fenvalerate microcapsules to cabbage, Chinese cabbage and cucumbers. The three plants did not differ much in phytotoxicity decreased with increasing in $T$. For example, the phytotoxicity to cucumbers was in order of No. 7 and No. 8, No. 6, No. 4, No. 3, No. 1 , No. 2. The microcapsules with $T$ of more than $0.051 \mu \mathrm{m}$ were not phytotoxic. $D$ was not a dominant factor to the phytotoxicity, although the relationship between phytotoxicity and $D$ was not clear.

Generally, a pesticide becomes phytotoxic when the active ingredient is in contact with a plant. The active ingredient should be released through the wall from microcapsules to cause phytotoxicity. For releasing the active ingredient, two mechanisms have been proposed: release by diffusion through the wall and breaking of microcapsules. As for the former, it has been reported that the release rate of the active ingredient is controlled by 


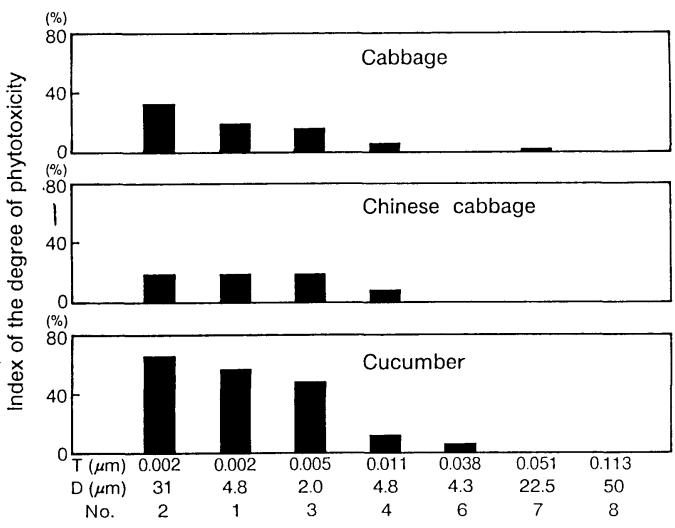

Fig. 5 Phytotoxicity of fenvalerate $10 \mathrm{wt} \%$ microcapsules.

No. in the figure, sample No. of fenvalerate 10 wt $\%$ microcapsule; $D$, Mass median diameter; $T$, wall thickness.

$D \cdot T$ and that it is inversely proportional to $D \cdot T{ }^{10)}$ In the later case, $D / T$ affects the strength of microcapsules and breaking of microcapsules increases with increasing in $D / T .^{9,13)}$

Thus, if the phytotoxicity of fenvalerate microcapsules is affected by the diffusion of fenvalerate through the wall, it decreases with decreasing in the release rate. As a result, the phytotoxicity decreases with increasing in $D \cdot T$. On the other hand, if the phytotoxicity is caused by the breaking of microcapsules, the phytotoxicity decreases with decreasing in the degree of the breaking. In this case, it decreases with decreasing in $D / T$. In both cases, it is expected that the phytotoxicity with the microcapsules decreases with increasing in $T$. This reasoning for the mechanism of phytotoxicity with microcapsules agrees with the experimental results described above. When the release by diffusion is a main mechanism, phytotoxicity decreases with increasing in $D$. On the contrary, when breaking is a main mechanism, it decreases with decreasing in $D$. Thus, if both mechanisms work at the same time, they counteract the effect of $D$. This may be the reason why the effect of $D$ was almost negligible.
3. Acute Oral Toxicity of Fenpropathrin 10 wt \% Microcapsules in Rats

It seems reasonable to assume that the active ingredient outside the wall is responsible for acute oral toxicity in the case of microencapsulated pesticides. As described above, there are two mechanisms for the release of the active ingredient from microcapsules, i.e., release by diffusion through the wall and breaking of microcapsules, and $D \cdot T$ affects the former while $D / T$ the latter.

Figure 6 shows the acute oral toxicity of

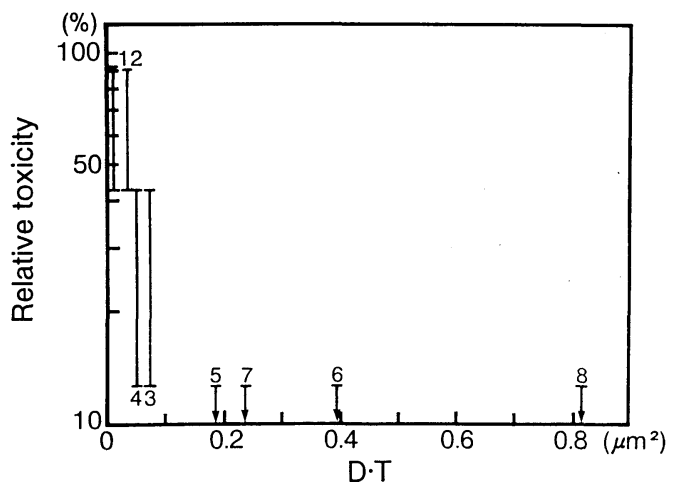

Fig. 6 Acute oral toxicity of fenpropathrin 10 $\mathrm{wt} \%$ microcapsules in rats.

No. in the figure, sample No. of fenpropathrin 10 wt $\%$ microcapsule; $D \cdot T$, product of mass median diameter and wall thickness; relative toxicity in rats, ratio of the acute oral toxicity of fenpropathrin $10 \mathrm{wt} \%$ emulsifiable concentrate to that of fenpropathrin $10 \mathrm{wt} \%$ microcapsule.

Table 5 Formulation factors of pyrethroid microcapsules to regulate their functions.

\begin{tabular}{lc}
\hline \multicolumn{1}{c}{ Item } & Formulation factor \\
\hline Initial efficacy & $D / T^{\mathrm{b}}$ ) \\
Residual efficacy & $D / T$ \\
Phytotoxicity $^{\mathrm{a}}$ ) & Mainly $T^{\mathrm{c})}$ \\
Rainfastness & Mainly $T$ \\
Fish toxicity & $D \cdot T^{\mathrm{d})}$ \\
Acute oral toxicity & $D \cdot T$ \\
\hline a) Mass median diameter $(D)$ is not a dominant \\
factor. \\
b) Mass median diameter/wall thickness. \\
c) Wall thickness. \\
d) Product of mass median diameter and wall \\
thickness.
\end{tabular}


fenpropathrin $10 \mathrm{wt} \%$ microcapsules in rats. The toxicity of the microcapsules relative to the fenpropathrin $10 \mathrm{wt} \%$ emulsifiable concentrate decreased with increasing in $D \cdot T$.

Thus, when the microcapsules are administrated orally to rats, it is supposed that the release rate of the active ingredient through the wall regulates the absorption of the active ingredient through the gastrointestinal organs.

We report the properties of pyrethroid microcapsules in the present and previous papers. ${ }^{10)}$ The formulation parameters of pyrethroid microcapsules to regulate the physicochemical, biological and toxicological properties are shown in Table 5.

\section{ACKNOWLEDGMENTS}

The authors express their thanks to Dr. T. Suzuki for his valuable advice for analyzing the result of acute oral toxicity of microcapsules and to Mr. Y. Manabe for his skillful technical assistance in preparing microcapsules. The authors are also indebted to Sumitomo Chemical Co., Ltd. for its permission to publish this work.

\section{REFERENCES}

1) K. Chiba, S. Yonemura \& S. Maeda (Hokko Chemical Industry Co., Ltd.): Jpn. Kokai Tokkyo Koho JP 59-193803 (1984)

2) H. Shiina, A. Kimura, K. Hiratsuka \& $T$. Nakamura (Ishihara Sangyo Kaisha Ltd.): Jpn Tokkyo Koho JP 63-37761 (1988)

3) S. Fujita, K. Adachi \& A. Sakamoto (Kumiai Chemical Industry): Jpn Kokai Tokkyo Koho JP 63-267701 (1988)

4) S. Tsuda, Y. Manabe \& K. Tsuji (Sumitomo Chemical Co., Ltd.): U.S. Patent US4871766 (1989)

5) T. F. Tadros: Pestic. Sci. 26, 51 (1989)

6) M. Klein: Isr. J. Entomol. 18, 83 (1984)

7) B. B. Petersen \& P. J. Shea: Weed Sci. 37, 719
(1989)

8) G. K. Noren \& M. F. Clifton: J. Coatings Technol. 58, 31 (1986)

9) T. Ohtsubo, S. Tsuda, H. Kawada, Y. Manabe, N. Kishibuchi, G. Shinjo \& K. Tsuji: J. Pesticide Sci. 12, 43 (1987)

10) T. Ohtsubo, H. Takeda, S. Tsuda, M. Kagoshima \& K. Tsuji: J. Pesticide Sci. 14, 235 (1989)

11) T. Ohtsubo, S. Tsuda, Y. Manabe \& K. Tsuji (Sumitomo Chemical Co., Ltd.): Jpn Kokai Tokkyo Koho JP 63-22004 (1988)

12) P. L. Madan, L. A. Luzzi \& J. C. Price: J. Pharm. Sci. 63, 280 (1974)

13) T. Ohtsubo, S. Tsuda \& K. Tsuji: Polymer (in press)

\section{要 約}

\section{耐雨性, 薬害およびほ乳動物毒性に影響を及ぼ} すピレスロイドマイクロカプセルの製剤要因

大坪敏朗, 竹田久巳, 津田重典, 辻 孝三 フェンバレレートマイクロカプセルおよびフェンプロ パスリンマイクロカプセルを用い，マイクロカプセルの 粒径 $(D)$ および膜厚 $(T)$ と耐雨性，薬害およびラッ トに対する急性経口毒性との関係について検討した．フ ェンバレレートマイクロカプセルの耐雨性は主として $T$ により制御され， $T$ が小さくなるほど耐雨性が向上し た.また $T$ が約 $0.05 \mu \mathrm{m}$ になった場合にはマイクロカ プセルはフェンバレレート乳剂よりも優れた耐雨性を示 した. $D$ の効果は無視できないもののその寄与は小さか った.フェンバレレートマイクロカプセルのキャベッ, ハクサイ，キュウリに対する薬害を調べた結果， $T$ が大 きくなるにつれ薬害は低下した。 $D$ の効果は明確ではな いが，その影響は小さいものと判断された. フェンプロ パスリンマイクロカプセルのラットに対する急性経口毒 性は $D \cdot T$ 值が大きくなるほど低下した。毒性は，マイ クロカプセルからの有効成分放出速度により制御されて いるものと推測された。 